\title{
Peran dan Tantangan Kerjasama Subregional dalam Mewujudkan Masyarakat Ekonomi ASEAN (MEA): Pendekatan Multilevel Governance
}

\author{
Budi Riyanto ${ }^{1}$
}

\begin{abstract}
Abstrak
Penelitian ini menganalisa pembentukan Masyarakat Ekonomi ASEAN (MEA) melalui pendekatan multilevel governance. Yakni, melihat dinamika integrasi ekonomi ASEAN dalam proses pengambilan kebijakan baik di tingkat makro-regional yakni pada level regional ASEAN, maupun mikro-regional yang dalam hal ini peranan di level subregional. Kapasitas kerjasama subregional sangat penting terutama sebagai dinamisator ekonomi di wilayah-wilayah terbelakang sekaligus sebagai wadah dalam menerapkan kebijakan alternatif untuk mencapai tujuan-tujuan integrasi ekonomi regional. Kemampuan ASEAN untuk mendorong penyempitan jarak kesenjangan pembangunan antara negara-negara CLMV (Kamboja, Laos, Myanamar dan Vietnam) dengan ASEAN6, serta kesenjangan konektivitas antara tiga subregional yakni GMS (Greater Mekong Subregion), IMT-GT (Indonesia-Malaysia-Thailand Growth Triangle), dan BIMPEAGA (Brunei Darussalam-Indonesia-Malaysia-Philippines East ASEAN Growth Area) sangat penting dalam upaya mendorong konvergensi kepentingan dan kohesivitas regional menuju kawasan yang berdaya saing.
\end{abstract}

Kata-Kata Kunci: multilevel governance, integrasi ekonomi regional, kesenjangan pembangunan, kesenjangan konektivitas, subregional.

\begin{abstract}
This research analyzes the formation of the ASEAN Economic Community (AEC) using multilevel governance approach. It sees through the dynamic integration of ASEAN in the process of policy-making both at macro-regional level that is the ASEAN regional level, as well as micro-regional role in this regard subregional. The capacity of subregional cooperation is particularly important as the economic dynamist in remote areas as well as the container in implementing alternative policies to achieve the objectives of regional economic integration. ASEAN's ability to drive the distance narrowing the development gap between CLMV countries (Cambodia, Laos, Myanamar and Vietnam) with ASEAN6, as well as the gap between the three subregional connectivity the GMS (Greater Mekong Subregion), IMT-GT (IndonesiaMalaysia-Thailand Growth Triangle), and BIMP-EAGA (Brunei Darussalam-Indonesia-MalaysiaPhilippines East ASEAN Growth Area) is very important in order to encourage the convergence of interests and regional cohesion towards regional competitiveness.
\end{abstract}

Keywords: multilevel governance, regional economic integration, development gap, connectivity gap, subregional.

\footnotetext{
${ }^{1}$ Penulis menamatkan studi S2 bidang Diplomasi dan Kebijakan Internasional Strategis di Universitas Paramadina. Fokus penelitian di bidang ekonomi politik internasional, studi pembangunan, dan studi diplomasi. Email: budiriyanto82@gmail.com
} 


\section{Pendahuluan}

Masyarakat Ekonomi ASEAN (MEA) menjadi target dalam level baru integrasi ekonomi di kawasan Asia Tenggara merupakan reaksi strategis untuk menjaga keunggulan komparatifnya di tengah semakin kompetitifnya persaingan di tingkat global. Negara-negara Asia Tenggara dinilai akan lebih diuntungkan jika liberalisasi ekonomi di tingkat regional terimplementasi, dibandingkan bersaing secara invidual secara langsung di tingkat global. Terlebih ASEAN berada di kawasan yang tengah berkembang pesat dan persaingan yang ketat di Asia Pasifik.

Dalam studi yang dilakukan The McKinsey (2003), ASEAN seharusnya mampu menjadi "surganya para investor". Dari beberapa indikator, ekonomi ASEAN memiliki potensi. Integrasi ekonomi ASEAN menyediakan populasi besar (yakni 591 juta atau $8,7 \%$ dari total 6,8 milyar jumlah penduduk dunia 2009) dengan nilai pasar konsumen lebih dari $\$ 330$ (consumer market) setara dengan kawasan dinamis di pesisir Cina, dan lebih besar dibandingkan dengan pasar manapun di Asia. Kombinasi sepuluh anggota ASEAN juga mengontrol $40 \%$ cadangan minyak dan gas di kawasan Asia Pasifik. ASEAN juga memiliki sektor sektor industri potensial dengan buruh yang relatif murah.

ASEAN perlu bertransformasi meningkatkan integrasi ekonominya menjadi pasar tunggal dan basis produksi, seperti citacita MEA yang termaktub dalam Deklarasi Bali Concord II di pada Konfrensi Tingkat
Tinggi (KTT) ASEAN tahun 2003. MEA diharapkan dapat menjamin pergerakan barang, jasa, modal, investasi, dan tenaga kerja ahli secara bebas. Deklarasi tersebut merupakan formalisasi dari Visi ASEAN 2020 yang disepakati pada KTT ASEAN di Kuala Lumpur tahun 1997. Implementasi MEA tahun 2015 merupakan percepatan yang disepakati dalam ASEAN Summit Januari 2007 yang menghasilkan Cebu Declaration on the Acceleration of the Establishment of ASEAN Community by 2015. Langkah percepatan integrasi ini dituangkan dalam cetak biru MEA dengan pilar-pilar antara lain, mewujudkan pembangunan yang berkeadilan, menciptakan basis produksi dan pasar tunggal ASEAN, menciptakan kawasan ekonomi yang berdayasaing, dan mendorong integrasi dengan ekonomi global.

Akan tetapi, mewujudkan pendalaman dan perluasan integrasi ekonomi regional melalui MEA tidaklah mudah. Kendala integrasi ekonomi juga tercermin dari minimnya porsi perdagangan intra-ASEAN yang belum banyak berkembang. Meski diakui ada peningkatan volume perdagangan yang cukup signifikan, yakni mencapai US $\$ 2,512$ miliar tahun 2013, namun porsi perdagangan intra-ASEAN masih dikisaran seperempat dari total perdagangan ASEAN. Pada tahun 2013, porsi perdagangan intra hanya sebesar $25 \%$. Kondisi ini tidak jauh berbeda dengan perdagangan intra-regional tahun 1993 saat AFTA dicanangkan dan 2003 saat MEA 
dideklarasikan yang memiliki porsi masingmasing 19,2\% dan 25,1\% secara berturut turut.

GRAFIK: Trend Nilai Perdagangan ASEAN dalam Persentase PDB

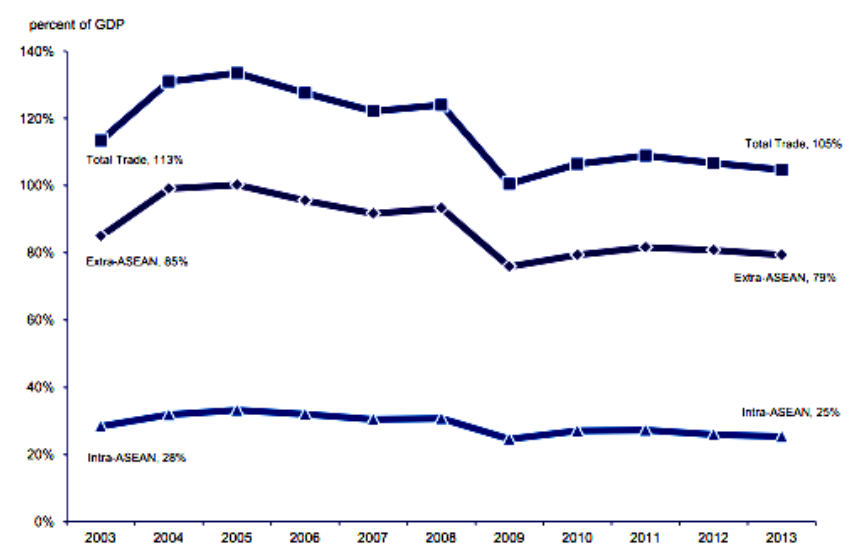

Sumber: Sekretariat ASEAN, AEC Chartbook 2014

Faktor penting yang menghambat terjadinya integrasi adalah karena masingmasing negara anggota ASEAN berangkat dari tingkat pembangunan yang berbeda. Di luar enam anggota pendiri ASEAN (ASEAN 6) yakni Brunei Darussalam, Indonesia, Malaysia, Filipina, dan Thailand yang lebih maju, negara -negara anggota baru yakni Kamboja, Laos, Myanmar dan Vietnam (CLMV) baru memulai transisi ekonomi. Sejak bergabungnya Vietnam pada tahun 1995, dilanjutkan oleh Laos dan Myanmar tahun 1997, dan Kamboja pada 1999, empat negara ini telah menambah sekitar
$28 \%$ dari total jumlah penduduk ASEAN, namun hanya menyumbang $7,8 \%$ terhadap GDP ASEAN pada 2004 (Yue: 2006), dan hanya menalami sedikit peningkatan menjadi kurang dari 9\% pada tahun 2009 (ACIF: 2010).

Program Initiative of ASEAN Integration (IAI) yang dibangun dengan tujuan untuk menyempitkan jarak kesenjangan antara ASEAN6 dan CLMV cukup banyak membantu mewujudkan MEA. Namun demikian program ini, banyak mendapatkan kritik baik dalam implementasi, kapasitas, 
komitmen politik, maupun soal pendanaan. Di sisi lain, meski pembangunan di CLMV masih di bawah performa ASEAN6, namun dinamika CLMV semakin pesat terutama dengan adanya Greater Mekong Subregion (GMS). Kawasan CLMV yang terletak di kawasan daratan ASEAN yang terhubung langsung secara geografis dengan Cina tentu menjadi faktor pendorong pembangunan. Geoff Wade (2010), melihat hal ini sebagai ancaman jangka panjang integrasi ekonomi di ASEAN. Terlebih Wade memprediksikan bahwa kedepannya GMS akan berkembang menjadi sebuah "region" tersendiri yang mapan sebagai sebuah basis produksi.

Di sisi lain, persoalan kesenjangan pembangunan tampaknya tidak bisa lagi dipandang dari satu sisi yakni antara anggota lama dan baru. Persoalan kesenjangan pembangunan yang terjadi di wilayah-wilayah lain juga berpotensi menghambat manfaat dari pembentukan integrasi ekonomi ASEAN. Konektivitas yang buruk di wilayah the Indonesia-Malaysia-Thailand Growth Triangle (IMT-GT) dan the Brunei Darussalam-Indonesia-Malaysia-Philippines East ASEAN Growth Area (BIMP-EAGA), tentu akan menjadi kendala dalam mengimplementasikan basis produksi dan pasar tunggal karena meski liberalisasi dilakukan secara masif melalui penghilangan hambatan tarif maupun non-tarif, tidak akan serta merta menjamin kemudahan akses sumber daya dan jalur distribusi. Dengan ketimpangan yang masih cukup tinggi dan tanpa konektivitas yang memadai integrasi ekonomi tidak akan mampu mendongkrak daya saing dan memberikan manfaat maksimal bagi anggotanya.

Revitalisasi pembangunan yang berimbang melalui mekanisme subregional yang sejatinya adalah untuk mendinamisasi perekonomian di wilayah-wilayah terbelakang ASEAN menjadi sangat perlu ditekankan, terutama dengan mengindentifikasi kelemahan-kelemahan dalam kerjasama subregional. Berbeda dengan GMS, IMT-GT dan BIMP-EAGA yang melingkupi wilayah kepulauan ASEAN dimana konektivitas maritim telah menjadi isu sentral.

\section{Pendekatan Multilevel Governance}

Pendekatan multilevel governance merupakan antitesa dari perkembangan teoriteori regionalisme lahir dalam perdebatan dua tradisi pendekatan di era tahun 1980an yakni, pendekatan supranasional di satu sisi, bertumpu pada pembantukan otoritas regional seperti federalisme, fungsionalisme, dan neofungsionalisme; dan pendekatan intergovermental di sisi lain, yang berbasis konsep kedaulatan (sovereignty-centric) antara lain neo-realisme, neoliberal institusionalisme, dan konfederalisme (Wunderlich: 2007). Pendekatan multilevel governance, mengkritik keras pendekatan-pendekatan tersebut dan mempelopori perkembangan studi new regionalisme. Merespon perkembangan hubungan internasional pasca Perang Dingin yang ditandai dengan munculnya perubahan 
ekonomi politik dunia dan semakin pentingnya kekuatan globalisasi.

Meski tidak secara langsung mengkonfrontasikan peran sentral negara dalam integrasi regional, namun pendekatan multilevel governance mengasumsikan bahwa otoritas negara tidak lagi menjadi tema sentral dalam pendekatannya. Kritik misalnya disampaikan oleh Gary Marks, Liesbet Hooghe dan Kermit Blank (1996), dengan mengidentifikasi keterbatasan negara -baik secara kolektif maupun secara individualdalam pembuatan kebijakan yang efektif. Bjorn Hettne dan Fredrik Söderbaum (1999) memperkenalkan istilah global social theory untuk menandai pendekatan ilmu sosial yang tidak lagi secara berat bertumpu pada negara bangsa sebagai basis analisa.

Istilah multilevel governance pertama kali digunakan oleh Gary Marks (1993) untuk melihat perkembangan dalam regionalisme di Eropa di tahun 1990an. Ia mendefinisikan sebagai: “... a system of continuous negotiation among nested governments at several territorial tier." Dalam hal ini Marks, membagi tingkat teritorial dalam supranasional, nasional, regional dan pemerintah lokal, dimana kesemuanya saling terkait satu sama lain dalam jaringan kebijakan.

Integrasi regional dalam pendekatan tersebut dilihat sebagai hasil dari interaksi dan negosiasi yang secara konstan dibangun di antara banyak aktor dalam beberapa level of governance baik secara vertikal maupun secara horizontal. Secara vertikal, integrasi regional merupakan hasil interaksi hubungan antar level baik supranasional atau regional, nasional maupun pemerintah lokal. Secara horizontal, peran non-state actor juga menjadi penting dalam melihat kompleksitas integrasi regional yang cenderung terlalu disederhanakan dalam teori-teori integrasi regional konvensional (Stubbs: 2005).

Senada dengan Marks, Fredrik Söderbaum (2005) mengusulkan istilah makroregionalisme dan mikro-regionalisme dalam pendekatannya. Makro-regionalism merujuk pada proses integrasi yang terjadi pada unit teritorial atau subsistem yang luas, yakni antara level negara dan level global. Subregional atau meso-regions juga dikategorikan masuk dalam tingkatan ini namun berada pada level yang lebih rendah dari regions. Sementara mikro-regionalisme didefinisikan sebagai kerjasama yang terjadi di antara level nasional dan level lokal atau daerah.

Pada tingkatan ini, mikro regionalisme dibagi menjadi dua yakni sub-nasional dan lintas batas (cross-border). Sub-nasional merujuk pada mikro-regionalisme konvensional yang murni terjadi di dalam sebuah negara karena lebih menganalisa antara hubungan vertikal administratif dan politik antara pemerintah pusat dan pemerintah daerah. Sementara, pada cross-border microregionalism kerjasama antara sektor publik dan 
swasta serta sejumlah aktor lokal lainnya terjalin secara horizontal; memiliki jaringan yang kuat di luar lintasi batas-batas negara; dan biasanya lebih banyak dimotivasi oleh tujuan ekonomi dibanding politik atau keamanan.

Dalam konteks ASEAN pendekatan multilevel governance menjadi alternatif dalam menjelaskan proses integrasi regional tanpa harus terjebak kedalam teori-teori yang berkembang di Eropa. Beberapa alasan sulitnya menerapkan teori-teori tersebut dalam integrasi di ASEAN antara lain, pertama, pendekatan supranasional misalnya sulit untuk diterapkan di ASEAN karena prinsip noninterference dan kecenderungan informalitas dalam prinsip keorganisasiannya. Kedua, pendekatan intergovermentalisme yang terlalu berat mengedepankan negara-bangsa dan kedaulatan, seperti neo-realisme, sangat terbatas dalam menjelaskan kerjasama internasional dan regionalisme. Sementara pendekatan neoliberal institusionalisme yang mengedepankan interdependensi kompleks memiliki kelemahan dalam menjelaskan integrasi ekonomi regional di ASEAN karena porsi perdagangan intra ASEAN yang sangat minim.

Terkait dengan isu kesenjangan pembangunan di ASEAN, pendekatan multilevel governance mampu menjadi alternatif untuk digunakan dalam menganalisa kompleksitas pengambilan kebijakan dalam kaitannya membangun integrasi ekonomi regional. Pengambilan kebijakan di ASEAN dalam melakukan penyempitan jarak kesenjangan di antara angotanya harus dilihat lebih dalam ranah level kebijakan regional baik antar anggota ASEAN maupun dengan mitra dialognya, sekaligus juga menganalisa pengambilan kebijakan pada ranah subregional.

\section{Peran Kerjasama Subregional di ASEAN}

Subregional memainkan peran penting dalam integrasi ekonomi ASEAN. Meski tidak melibatkan anggotanya secara keseluruhan, kerjasama subregional di ASEAN dipandang mampu menjadi fasilitator dan pelengkap kerjasama ditingkat regional. Min and Myo (1993) mendifinisikan growth triagles atau kerjasama subregional sebagai zona ekonomi transnasional yang terbentang luas dengan batas tertentu, meliputi tiga atau lebih negara yang memiliki kedekatan wilayah dimana perbedaan faktor pendukung dieksploitasi untuk mempromosikan perdagangan dan investasi external.

Keunggulan utama dan manfaat dari kerjasama subregional menurut Chia Siow Yue (1997) sangat terkait dengan keterbatasan dalam menjalin kerjasama di tingkat regional secara utuh. Pertama, kerjasama subregional menjadi alternatif terhadap kendala integrasi ekonomi regional yang dihadapi negara-negara anggota terkait dengan perbedaan tahap pembangunan ekonomi dan perbedaan sistem ekonomi dan politik. 
Kedua, kerjasama subregional lebih mudah dikelola secara politik dan lebih fleksibel secara fungsi karena memiliki lingkup yang lebih terbatas. Kerjasama dalam lingkup yang lebih kecil ini menjadi alternatif terhadap kesulitan dan kendala yang timbul dari kerangka kerjasama ekonomi dan politik yang komlpeks dan penuh risiko di tingkat regional. Ketiga, kerjasama subregional mempermudah para pengambil kebijakan untuk lebih fokus dalam membangun wilayahwilayah ekonomi yang terbelakang dan terpinggirkan melalui upaya menghubungkannya dengan wilayah yang lebih yang lebih maju. Keempat, kerjasama subregional terfokus pada ekonomi yang saling melengkapi (economic complementarity) dalam menarik investasi.

$$
\text { Jose L. Tongzon }
$$
mengidentifikasi beberapa hal yang membuat kerjasama subregional yang ada di ASEAN menjadi building block dari kerjasama regional ASEAN secara keseluruhan, diantaranya, kerjasama subregional dianggap mampu membangun rasa percaya diri dan saling percaya untuk menjalin kerjasama yang lebih besar di tingkat regional. Kerjasama subregional juga menjadi ranah ujicoba dan menjadi alat dalam mentransformasi keunggulan komparatif nasional menjadi keunggulan komparatif regional. Bentuk kerjasama subregional juga menyediakan mekanisme yang pragmatis dan efektif dalam mengintegrasikan dan mendinamisasi wilayahwilayah dengan keterbelakangan pembangunan. Selain itu, subregionalisme mendorong kerjasama regional melalui proses economization of politics, dengan meredakan ketegangan di ranah politik dan kemanan, serta mengedepankan persamaan terutama kerjasama ekonomi yang saling menguntungkan.

\section{Transformasi Besar di Greater Mekong} Subregion (GMS)

Terkait dengan Konektivitas ASEAN dalam mewujudkan MEA 2015, ASEAN dihadapkan pada kenyataan geopolitik terutama kemajuan pesat di wilayah Greater Mekong Subregion (GMS) yang meliputi sebagian besar wilayah daratan ASEAN yakni negara-negara CLMV, Thailand, dan pada saat yang bersaaan melibatkan China (khususnya Propinsi Yunnan dan Daerah Otonom Guangxi Zhuang). Wilayah GMS memiliki populasi gabungan sekitar 326 juta serta luas 2,6 juta kilometer persegi (ADB: 2011). GMS merupakan model suksesnya transformasi ekonomi dan integrasi di antara negara-negara berkembang.

Meski di tahun 1970an dan 1980-an Asia mengalami pertumbuhan ekonomi yang pesat dan membuka diri terhadap ekonomi global, GMS justru merupakan kawasan yang sangat miskin dan terisolasi. Stabilitas politik yang tidak menentu, konflik yang berkepanjangan serta model ekonomi yang 
tersentralisasi merupakan penyebab utamanya.

Kini GMS merupakan subregional paling dinamis di dunia dengan pertumbuhan yang paling pesat dibandingkan seluruh Asia Timur dan Pasifik.

Sumbangan pertumbuhan yang besar datang dari negara-negara CLMV yang mulai melakukan reformasi dan liberalisasi secara bertahap sejak paruh kedua 1980-an. Negaranegara CLMV juga tetap tumbuh saat banyak negara mengalami krisis ekonomi tahun 1997/1998 termasuk Thailand, Singapura, Malaysia dan Indonesia. Sejumlah program yang dijalankan di wilayah GMS juga telah mampu mentransformasi struktur ekonomi yang sebelumnya didominasi oleh agraris subsisten menjadi lebih peka terhadap keunggulan komparatif, begitu juga dengan peningkatan pendapatan ekonomi dan indikator kesejahteraan lainnya (Menon dan Melendez: 2009).

Kemajuan pesat di GMS tersebut tentu tidak dapat dipisahkan dari sejumlah megaproyek yang terintegrasi yang mampu mentransformasi konektivitas infrastruktur dan koridor transportasi menjadi koridor ekonomi yang utuh. Kawasan ini juga akan semakin dinamis dengan penerapan inisiatif-inisiatif untuk menggiatkan fasilitasi perdagangan dan investasi (Wade: 2010). Pada tahun 2007, menteri-menteri di GMS juga telah menyetujui perluasan koridor ekonomi lain sehingga total menjadi sembilan koridor ekonomi. 
GAMBAR: Koridor-koridor Ekonomi di Greater Mekong Subregion

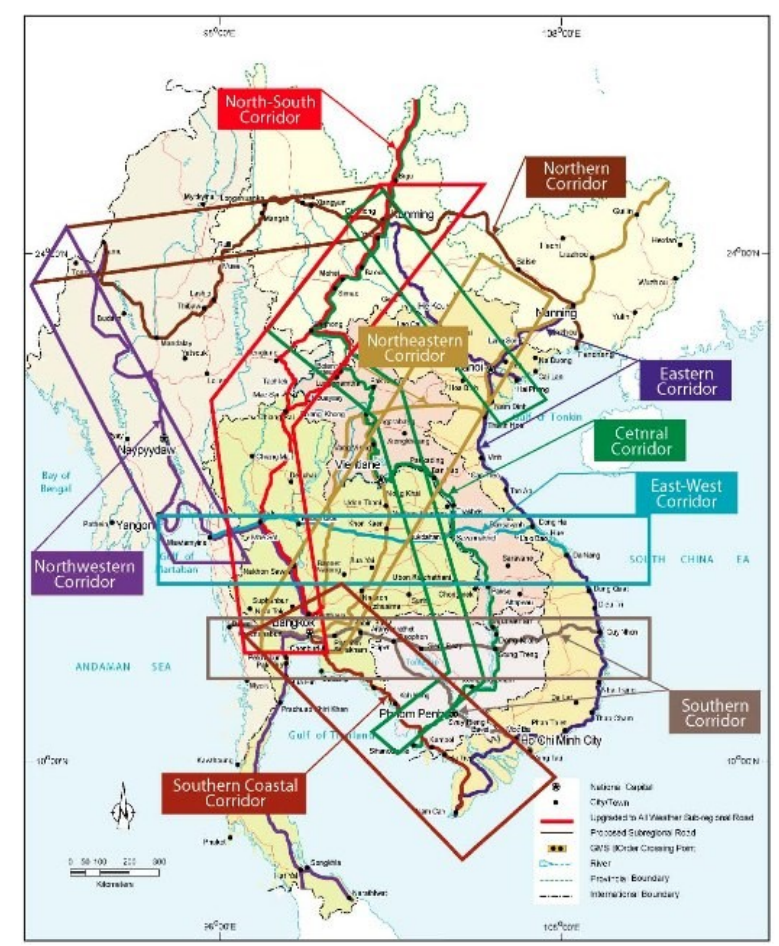

Sumber: Asian Development Bank (2007)

Kesuksesan besar GMS juga didukung oleh komitmen para pemimpin di GMS untuk menjalin kerjasama ekonomi sub-regional. Para pemimpin GMS telah menandatangani deklarasi bersama melalui KTT GMS yang pertama kali diadakan di Phnom Penh, Kamboja pada 3 November 2002. Komitmen untuk meningkatkan konektivitas juga terlihat dari adanya usaha keras untuk menerapkan Cross Border Transport Agreement (GMSCBTA), yakni melengkapi konektivitas infrastruktur fisik dengan dimensi infrastruktur non-fisik seperti penerapan visa multy-entry, izin mengemudi bersama, sistem inspeksi yang terintegrasi dan lain-lain. Di samping itu, negara-negara GMS juga telah menjadikan konektivitas sebagai agenda pembangunan nasional masing-masing.

Namun demikian, meski terlihat perkembangan yang sangat baik dalam peningkatan konektivitas infrastruktur terutama untuk konektivitas transporatasi dan pembangkit listrik, dalam, laporan midterm GMS Strategic Framework (2002-2012) oleh ADB pada tahun 2007 misalnya terlihat adanya kelemahan dalam peningkatan daya saing ekonomi. Studi ADB (2011) menunjukkan adanya perkembangan pesat terkait kebijakan dan performa perdagangan maupun investasi, meski sejumlah catatan penting masih menjadi persoalan, di antaranya masih banyaknya hambatan non-tarif dan 
belum terselesaikan reformasi fasilitasi perdagangan, serta besarnya persepsi dari pemerintah maupun pembuat kebijakan bahwa negara-negara GMS masih sangat rentan terhadap external shock (Menon dan Melendez: 2011).

Sejak tahun 1992, proyek GMS telah berperan besar dalam pembangunan infrastruktur dan menciptakan interaksi, aliansi, interdependensi, dan keterhubungan baru di wilayah daratan Asia Tenggara melalui investasi. ADB telah mengucurkan pendanaan untuk proyek infrastruktur lebih dari US\$ 11 miliar baik yang telah selesai atau sedang dilaksanakan, terutamaEast-West Economic Corridor yang menghubungkan Laut Andaman (pantai Myanmar) ke Laut Cina Selatan (Da Nang di Vietnam). Sementara itu, Jepang juga punya kontribusi yang signifikan melalui Japan International Cooperation Agency (JICA) dan Japan Bank for International Cooperation (JBIC) (Stone and Strutt: 2009).

Jauh sebelum proyek GMS dikembangkan, Komisi Ekonomi dan Sosial untuk Asia dan Timur Jauh (ESCAP) atau yang sebelumnya dikenal dengan ECAFE, telah membuat program khusus untuk wilayah sungai Mekong pada tahun 1957, dengan mendirikan the Committee for the Coordination of Investigations of the Lower Mekong Basin atau yang lebih dikenal dengan the Mekong Committee.

Sejumlah kerjasama juga dicanangkan oleh negara-negara sepeti Selandia Baru bahkan Australia. Tahun 1996, pemerintah Thailand dan Selandia Baru bekerjasama mendidikan dan mendanai Mekong Institute yang berpusat di kampus Khon Kaen University di sebelah timur laut Thailand. Sementara, Australia yang memberikan sumbangsih besar dalam pembangunan Friendship Bridge yang menghubungkan propinsi Nong Khai di Thailand dengan wilayah administrasi Viantiane di Laos (Severino: 2007).

India juga memainkan peran strategis di wilayah daratan ASEAN melalui pembangunan rute Thailand-Myanmar-India yang akan menjadi jalan raya transportasi kargo antara India dan negara-negara ASEAN. India juga berkepentingan besar dengan pelabuhan Ranong di Thailand yang telah dibuka pada 2003. Jika dari Bangkok ke Asia Selatan melalui Malaysia dan Singapura membutuhkan 25 hari, jalur melalui Pelabuhan Ranong mampu memotong waktu tempuh menjadi 4 hingga 7 hari (Suteethorn: 2009).

Dari semua kerjasama tersebut kerjasama kepentingan Cina perlu digarisbawahi. Cina memiliki kepentingan strategis yang besar untuk pengembangan wilayah hilir sungai Mekong untuk memastikan adanya pasokan bahan baku untuk menunjang perekonomian sekaligus memelihara kepentingan di ASEAN. Kini, pengaruh dominasi Cina di GMS semakin besar baik dalam kapasitas sebagai sponsor dan sebagai partisipan sekaligus. ASEAN 
mengembangkan kerjasama dengan Cina yang didedikasikan untuk pembangunan wilayah Mekong dengan mendirikan AMBDC, contohnya pembenahan dan jalur kereta api Singapore-Kunming atau SKRL. Cina juga berinvestasi untuk pembangunan pembangkit listrik tenaga air (hydropower) dengan memanfaatkan sungai Mekong. Selain menunjukkan tingkat ketergantungan investasi infrastruktur dari Cina, pembangunan bendungan ini juga memiliki pengaruh besar terahadap kontrol Cina pada sektor agraria di negara-negara daratan ASEAN.

Besarnya kepentingan ekonomi politik Cina di wilayah daratan ASEAN ini telah menimbulkan kekhawatiran. Bagi kekuatankekuatan besar seperti Amerika Serikat, Jepang, Korea Selatan dan India yang juga memiliki kepentingan besar di kawasan Asia Timur dan ASEAN, membesarnya hal tersebut akan menjadikan wilayah negara-negara ASEAN, kuhususnya wilayah daratan, jatuh pada pengaruh Cina. Amerika Serikat misalnya telah mengimbangi pengaruh tersebut dengan masuk sebagai donor di River Mekong Commission (MRC) yang melibatkan Kamboja, Laos, Thailand dan Vietnam, namun Cina menolak keikutsertaanya dalam organisasi tersebut. Penolakan Cina dan Myanmar secara efektif melemahkan KTT MRC pertama pertengahan 2010 di Thailand.

IMT-GT Sebagai Dinamisator Wilayah Tengah ASEAN

Indonesia-Malaysia-Thailand Growth
Triangle (IMT-GT) merupakan program kerjasama ekonomi subregional yang didirikan pada tahun 1993 dengan tujuan mempercepat transformasi provinsi di tiga negara dengan menekankan adanya perdagangan yang bersifat komplementer dan berdasarkan pada keunggulan komparatif. Keanggotaan IMT-GT telah mencakup 32 provinsi dan negara bagian, 14 di antaranya meliputi bagian selatan Thailand, kemudian delapan 8 bagian di semenanjung Malaysia, dan melibatkan 10 provinsi di wilayah Sumateran di Indonesia. Kerjasama ini dimotivasi oleh kebutuhan untuk mendorong pertumbuhan ekonomi di wilayah-wilayah terbelakang, terutama di Sumatera dan bagian selatan Thailand untuk dapat mengejar pembangunan wilayah lain yang lebih maju, dan dapat mengambil manfaat dari pertumbuhan ekonomi dan integrasi.

IMT-GT memiliki modal penting sebagai blok kerjasama ekonomi alamiah karena sifat perdagangannya yang saling melengkapi (komplementer), kedekatan geografis, kedekatan historis, budaya, dan bahasa. IMT-GT secara umum mengandalkan pertanian, dengan tanah yang luas serta kaya sumberdaya alam yang cukup potensial untuk meningkatkan pertumbuhan ekonomi, mengurangi kemiskinan, dan memperbaiki kualitas hidup penduduknya yang berjumlah sekitar 72 juta (2006). Dengan daya dukung pemerintah dan sektor swasta, beberapa inisiatif telah dilahirkan baik di bidang 
perdagangan, travel dan pariwisata, dan juga peningkatan konektivitas fisik di wilayah tersebut.

Namun demikian, perkembangan awal program kerjasama yang diinisiasi di IMT-GT menemui banyak kendala sehingga berjalan kurang efektif dalam mewujudkan visinya. Krisis finansial 1997 utamanya, telah membuat kerjasama ekonomi subregional termasuk IMT -GT lumpuh karena menurunnya prioritas dan komitment pemerintah, dan lesunya perekonomian ditengah ketidakpastian dan ketidakstabilan. Sejak akhir tahun 1990-an hingga awal 2000-an kerjasama IMT-GT tidak berfungsi.

Kebutuhan menghidupkan kembali kerjasama subregional kembali dirasakan mendesak untuk mendorong pertumbuhan dan pembangunan pasca krisis. Pada Desember 2005, ASEAN menghidupkan kembali subregional di kawasan tersebut malalui KTT pertama IMT-GT di Malaysia. Dua tahun, kemudian pada KTT ke dua IMT-GT di Kota Cebu, Filipina pada Januari 2007 para pemimpin juga menyepakati IMT-GT Roadmap for Development 2007-2011 sebagai panduan dalam memformulasikan dan mengimplementasikan program pembangunan berdasarkan target dan jadwal yang jelas termasuk mekanisme koordinasi, pengawasan, dan evealuasi. Roadmap tersebut juga menyediakan landasan dalam memobilisasi sumberdaya melalui kerjasama bilateral dan agen pembangunan multilateral, investor swasta, serta institusi multilateral (IMT-GT Secretariat and ADB: 2008).

Kemudian pada KTT IMT-GT ke 4 di Thailand pada Februari 2009, para pemimpin mulai merasakan perlunya memperkuat implementasi program yang terkait dengan IMT-GT Connectivity Corridor dengan merangkul ADB dalam mengindentifikasi, menetapkan prioritas dan pembiayaan proyek tersebut. Agenda mendesak ini juga menjadi pembahasan pada Senior Officials Meeting dan Pertemuan tingkat Menteri. Komitmen tersebut menandai arah kebijakan IMT-GT menjadi lebih berorientasi pada proyek pembangunan yang kongkrit. 
Gambar: Lima Koridor Konektivitas IMT-GT

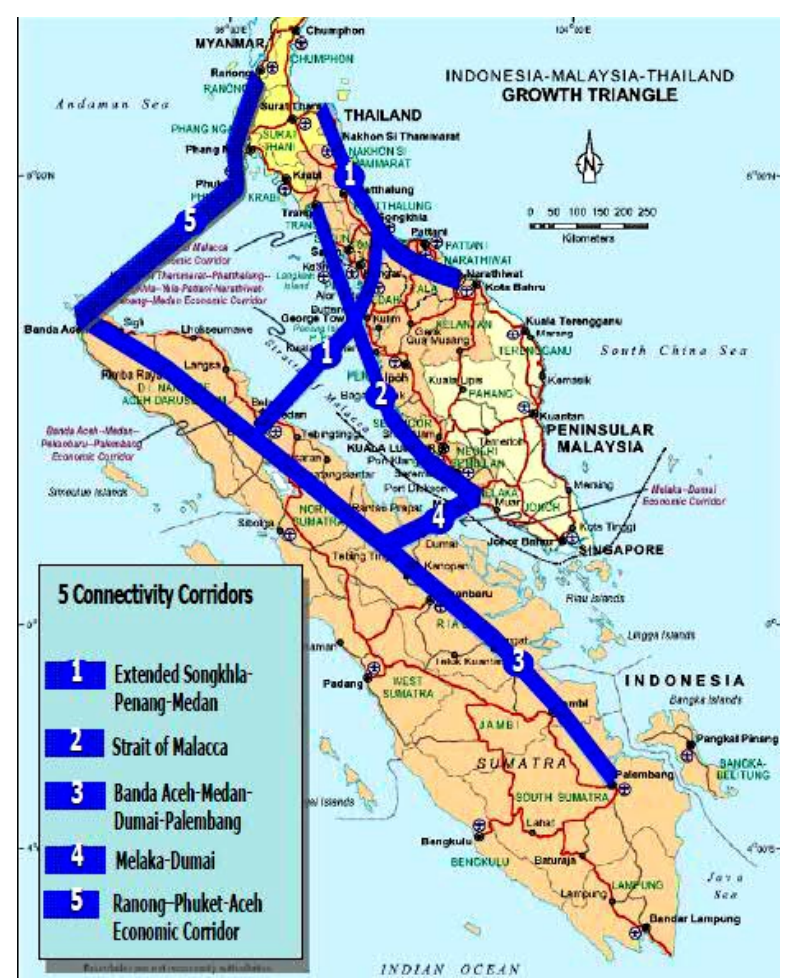

Sumber: IMT-GT

Pembangunan infrastruktur di IMT-GT merupakan bagian dari usaha mengintegrasikan secara fisik untuk mendorong klaster yang digariskan dalam lima koridor konektifitas tersebut. Meski sejumlah proyek infrastruktur terutama transporatasi darat, laut dan udara di IMT-GT telah mulai dibangun, namun persoalan teknis, pendanaan, dan peraturan masih menjadi kendala dan menyebabkan sejumlah proyek yang telah direncanakan harus ditunda. Sementara terkait bidang energi, IMT-GT masih belum berhasil membangun strategi dan program kerjasama, meski kemungkinan untuk membangun kerjasama di sektor tersebut telah dibahas.
Sejumlah proyek infrastruktur juga telah diusulkan masuk dalam rencana kerja 20122016, termasuk meningkatkan kapasitas dan efektivitas transporatasi laut dengan sistem RoRo, kemudian membangun dan meningkatkan kualitas jalan raya yang menjadi bagian dari Asian Highway, membangun missing link jalur kereta api yang menjadi bagian dari SKRL dalam kaitan ini jalur kreta api di wilayah Sumatera masih pada tahap studi-, dan juga terkait dengan recana membangun perjanjian fasilitasi transportasi dengan membentuk Working Group on Transport Facilitation.

BIMP-EAGA dan Ketimpangan di Wilayah Kepulauan 
Brunei Darussalam-IndonesiaMalyasia-Filipina East ASEAN Growth Area (BIMP-EAGA) dibentuk pada tahun 1994 dengan tujuan strategis yakni meningkatkan pastisipasi pemerintah dalam mengatasi persoalan-persoalan sosial dan pembangunan ekonomi di wilayah-wilayah yang masih terberlakang dan terpencil. Kerjasama lintas batas negara di wilayah timur ASEAN ini meliputi beberapa wilayah di antaranya, Brunei Darussalam, lalu beberapa provinsi di Indonesia mencakup Sulawesi, Kalimantan, Maluku dan Papua di Indonesia; lalu Sarawak dan Labuan di Malaysia; serta Mindanao dan Palawan di Filipina.

Krisis finansial Asia 1997 secara keseluruhan juga berdampak pada kerjasama subregional BIMP-EAGA secara cukup signifikan terutama hilangnya kepercayaan diri dalam bekerjasama, menurunnya kunjungan wisatawan, dan minimnya mintat untuk menanamkan investasi. Meski begitu, sejak krisis mereda ASEAN segera mengambil langkah cepat dengan menghidupkan kembali peran BIMP-EAGA melalui KTT ASEAN ke 7 pada November 2001. Komitmen berhasil membuka jalan dalam merevitalisasi kegiatan dan kerjasama ekonomi lintas batas. BIMPEAGA memperluas perspektifnya dari yang sebelumnya hanya berfokus pada perdagangan inter-EAGA menjadi lebih luas baik di tingkat regional mupun global. Pendekatan pembangunan juga dalam hal ini berubah dengan menekankan pada peningkatan keunggulan daya saing di pasar dunia melalui konsolidasi lintas batas, saling melengkapi, klaster industri dan tata kelola value chain. BIMP-EAGA juga telah melakukan pembenahan institusional untuk menanggapi perubahan baru tersebut dengan membentu BIMP Facilitation Center, membentuk kelompok kerja berdasarkan cluster, serta merestrukturisasi East ASEAN Business Council menjadi BIMP-EAGA Business Council.

Untuk menjadi panduan dalam menjalankan kegiatan dan proyek pembangunannya, BIMP-EAGA membentuk BIMP-EAGA Roadmap to Development melalui Senior Official Meeting (SOM) ke 12 atau Pertemuan tingkat Menteri ke 9 di Balikpapan pada November 2004. Dalam pembentukan roadmap tersebut, BIMP-EAGA Facilitation Center dibantu oleh Sekretariat ASEAN dalam mengumpulkan, memvalidasi dan mengkonsolidasikan masukan dari pemangku kepentingan. ADB dan juga German Technical Cooperation Agency (GTZ) juga berperan besar dalam menyediakan banguan tekhnis.

Sebagaimana sudah dibahas sebelumnya, meski kesenjangan pembangunan antara negara-negara CLMV dan ASEAN6 bisa terlihat dari beberapa indikator sosial ekonomi, namun persoalan kesenjangan di internal ASEAN6 juga merupakan isu penting terutama bagi Indonesia dan Filipina. Baik di Indonesia maupun Filipina tantangan untuk 
memperbaiki transportasi maritim merupakan agenda mendesak untuk mengatasi kesenjangan pembangungan sekaligus mengentaskan kemiskinan. Kerjasama subregional BIMP-EAGA memiliki peran penting mendinamisasi perekonomian di wilayah ini.

Di Indonesia, berdasarkan data resmi Badan Pusat Statistik (BPS) tahun 2010, provinsi yang memiliki tingkat kemiskinan tinggi sebagian besar berada di wilayah timur Indonesia yang juga merupakan mata rantai terlemah dalam konektivitas ASEAN antara lain Papua dengan jumlah penduduk miskin mencapai 36,80 persen, Papua Barat 34,88 persen, Maluku 27,74 persen, Gorontalo 23,19 persen, Nusa Tenggara Timur 23,03 persen dan Nusa Tenggara Barat 21,55 persen. Sementara itu, lima dari sepuluh provinsi termiskin di Filipina termasuk ke dalam wilayah yang dikategorikan sebagai provinsi pulau (island province), termasuk di antaranya Sulu (ARMM/Automous Region in Muslim Mindanao) dan provinsi Masbate yang memiliki tingkat insiden kemiskinan 63 persen, begitu juga provinsi Tawi-Tawi, Romblon dan Caminguin dengan tingkat insiden kemiskinan di atas 50 persen.

Tantangan utama dalam kerjasama di BIMP-EAGA adalah minimnya konektivitas dan belum terbentuknya koridor-koridor ekonomi. Konektivitas di wilayah yang merupakan kantong ketertinggalan di kepulauan ASEAN ini misalnya dicirikan dengan, pelabuhan sekunder yang kebanyakan memiliki fasilitas yang rendah, tidak terkoneksi dengan baik dengan daratan karena kualitas jalan raya yang buruk, dan masih didominasi oleh kapal-kapal laut yang kecil. Dibandingkan dengan Singapura yang memiliki armada kapal yang besar dan baru, Indonesia dan Filipina sangat tegantung pada armada kapal yang kecil dan sudah tua (ADB: 2010).

Karena itu, program konektivitas menjadi program yang paling menonjol dalam kerjasama di subregional ini seperti tertuang dalam Master Plan on ASEAN Connectivity (MPAC). BIMP-EAGA memandang penting konektivitas sebagai salah satu instrumen kunci dalam mewujudkan visi BIMP-EAGA sebagai salah satu lumbung pangan dan pusat pariwisata alam di ASEAN dan wilayah lain di Asia. Para pemimpin BIMP-EAGA dalam pertemuannya di Hua Hin, 28 Oktober 2011 telah menetapkan BIMP-EAGA Infrastructure Project Pipeline (PIP). Sejak tahun 2007, BIMP-EAGA telah menandatangani beberapa MoU dalam bidang perhubungan. Di antaranya MoU on Establishing and Promoting Efficient and Integrated Sea Linkages (EPEISL) pada 2007.

Sebagai implementasi MoU tersebut, maka sejak Desember 2009 telah beroperasi Roll On/Roll Off Passenger Ferry antara Muara, Brunei Darussalam dan Menumbok, Malaysia. Demikian pula, jasa pelayaran antara Bitung-Tahuna, Indonesia dan Glan, Filipina 
mulai dilaksanakan sejak Maret 2010. Di masa mendatang Ro-Ro diharapkan dapat segera melayani rute Muara, Brunei Darussalam--Labuan, Malaysia. Sementara itu, sebagai implementasi $M o U$ on Cross Border Movement of Commercial Busses and Coaches sekitar 40.000 orang dalam kurun waktu Januari-Desember 2009 telah menggunakan jasa bus lintas wilayah BIMP-EAGA (Pontianak-Bandar Seri Begawan).

Gambar 4.7: Koridor-koridor Ekonomi di BIMP-EAGA

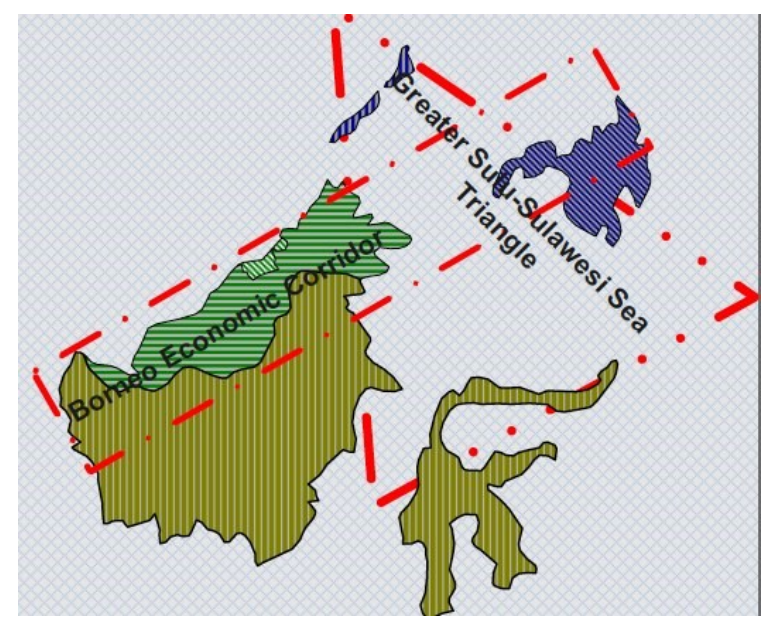

Sumber: $A D B 2004$

Gambar di atas menunjukkan beberapa potensi koridor ekonomi yang ada di BIMPEAGA. Borneo Economic Corridor (BEC) terletak di wilayah sebelah barat Kalimantan, yang teridiri dari Kalimantan Barat, Serawak, Sabah, dan Brunei. Koridor ekonomi ini memiliki infrastruktur fisik yang sudah terbangun dan memiliki tingkat perdagangan dan investasi yang natural. Sementara Greater Sulu-Sulawesi Seas Triangle (GSSST) meliputi Sulawesi Utara, Mindanao, dan Sabah dan utamanya diikat secara geografis oleh laut Sulu dan Sulawesi, memiliki pola perdagangan 
historis yang terhubung dengan baik meski masih relatif minim.

Meski banyak inisiatif yang lahir dari kerjasama subregional BIMP-EAGA dan IMTGT, namun beberapa studi telah menunjukkan adanya kebutuhan untuk mereorganisasi struktur institusional mereka terkait dengan kelemahan dalam menyusun perencanaan proyek, formulasi proyek dan implementasi proyek. Dalam laporan jangka menengah BIMP-EAGA Roadmap to Development (20062010) tahun 2008 terlihat adanya kelemahan pada perencanaan program dan mekanisme implementasi. Hal ini terkait dengan struktur organisasi BIMP-EAGA dinilai lebih cocok untuk konsultasi dan bukan untuk implementasi proyek. Kelemahan serupa juga terlihat dalam kerangka kerjasama IMT-GT. Pada evaluasi jangka menengah IMT-GT Roadmap for Development (2007-2011) tahun 2010 serta Business Process Review (BPR) yang dilakukan secara paralel ditegaskan bahwa kelemahan kapasitas institusional menjadi penyebab utama lambannya perkembangan dalam implementasi roadmap tersebut. Selain itu, IMT-GT juga dinilai memiliki respon yang lemah terhadap dinamika sektor swasta.

Kelemahan lain dari kerjasama IMTGT Sarah Y. Tong and Catherine Chong Siew Keng (2011) terletak pada kemampuan menjalankan transformasi ekonomi yang berkelanjutan. Sulitnya akses finansial dan kelangkaan pasokan listrik menjadi kendala dalam pengembangan bisnis. Tantangan serius juga tengah dihadapi kerjasama subregional ini seperti meningkatnya kompetisi dengan munculnya kekuatan ekonomi baru terutama Cina dan India. IMT-GT perlu lebih keras dalam mempercepat menerapkan liberalisasi, simplifikasi dan harmonisasi terkait dengan investasi, perdagangan barang dan jasa, dan mobilisasi tenaga kerja. Di BIMP-EAGA persoalan yang dihadapi juga tak kalah kompleks, meski kaya akan sumberdaya alam baik lahan pertanian, hutan tropis, minyak, gas alam dan batubara, transformasi ekonomi yang bercorak agrikultur menjadi manufaktur masih sulit dilakukan. Sebagai contoh, Ayala de Zamboanga Industial Park di Filipina tidak mampu mengambil manfaat dari kerjasama subregional dalam menarik investasi, karena tidak adanya sifat komplementer yang kuat antara satu dengan lainnya, selain faktor ketersediaan infrastruktur yang buruk dan ketidakstabilan politik.

\section{Kesimpulan}

Kerjasama subregional jelas memiliki peran penting dalam menyempitkan jarak kesenjangan pembangunan, dan dengan demikian mendorong terwujudnya MEA yang bermanfaat bagi seluruh anggota ASEAN. Tiga program subregional yakni GMS, IMTGT, dan BIMP EAGA memberi ruang dalam mendinamisasi pembangunan di wilayahwilayah tertinggal melalui mekanisme kebijakan yang lebih fleksibel dibandingkan dengan mekanisme ASEAN secara 
keseluruhan meski tentunya tidak bisa dipisahkan satu sama lainnya. Kerjasama subregional menjadi sarana dalam mengembangkan pemikiran, praktik dan pendekatan baru menuju integrasi ekonomi yang bermanfaat bagi negara-negara anggota ASEAN.

Pendekatan Subregional di ASEAN setidaknya bisa menjadi alternatif dari ketegangan yang muncul dari doktrin nonintervensi di tingkat regional ASEAN, yakni dengan mempromosikan manfaat kerjasama pembangunan tanpa harus banyak bersitegang mengenai kedaulatan, politik, keamanan dan isu-isu sensitif lainnya. Kerjasama subregional juga diharapkan mendorong proses bottom up untuk mengimbangi pendekatan top down yang selama ini dijalankan oleh ASEAN. Program-program subregional mendorong kerjasama ekonomi regional yang berbasis pada kebutuhan pasar, untuk mengimbangi proses kerjasama pembangunan dan integrasi ekonomi regional ASEAN yang cenderung didominasi oleh kesepakatan-kesepakatan antar pemerintah secara nasional. Dengan demikian, subregionalisme memfasilitasi kerangka kerjasama yang juga melibatkan pemerintah daerah dalam perencanaan pembangunan dan kerjasama ekonomi.

Proses bottom up dalam kerjasama subregional juga diharapkan mampu mendorong peran swasta dan dunia bisnis dalam dalam mendorong kemanfaatan liberalisasi ekonomi. Terlebih, porsi perdagangan intra-ASEAN yang sangat minim jelas tidak memberikan insentif bagi perkembangan peran swasta dalam proses integrasi di ASEAN. Model kerjasama di tingkat subregional lebih fokus pada kegitatankegiatan yang dapat memfasilitasi pergerakan barang dan orang lintas territorial dan memberikan insentif bagi sektor swasta untuk mengambil manfaat dari kesempatan bisnis yang terbangun.

Kerjasama subregional juga memainkan peran penting dalam mefokuskan kebijakan pada persoalan lingkup yang lebih kecil. Sejak pendalaman ekonomi ASEAN di bawah MEA dituangkan ke dalam blueprint, peran kerjasama subregional jelas semakin mendesak untuk ditingkatkan dalam memenuhi skema kerjasama dengan jadwal dan target yang ketat. Persoalan-persoalan ketimpangan pembangunan dan konektivitas dalam hal ini, merupakan wilayah-wilayah yang sangat perlu didorong melalui kerangka kerjasama subregional.

Tingkat perdagangan intra regional ASEAN yang hanya seperempat dari total perdagangan juga sulit ditingkatkan lantaran karakter perdagangan intra ASEAN yang lebih bersifat kompetitif dan bukan komplementer (Landingin dan Wadley: 2005). Dengan demikian kerjasama subregional harus didorong untuk mengatasi hal tersebut dengan mendorong spesialisasi produksi berdasarkan keunggulan komparatif dengan modal utama 
sebagai blok ekonomi yang natural dimana perdangangan bersifat komplementer.

Selain keleman-kelemahan di internal masing-masing subregional, kerjasama subregional kurang berjalan secara efektif karena kelemahan ASEAN dalam mengelola tiga program subregional tersebut. Persoalan ini tentu akan menjadi kendala bagi ASEAN dalam usaha menyepitkan jarak kesenjangan pembangunan karena berpotensi menimbulkan tumpang tindih dan duplikasi kegiatan. Program IAI yang fungsi utamanya adalah untuk menyempitkan jarak kesenjangan pembangunan, sebagaimana telah diterangkan, memiliki kelemahan mendasar dalam melakukan koordinasi antar lembaga dan mekanisme pengawasan (ASEAN Secretariat: 2005).

Terdapat beberapa hal menjadi problem koordinasi dan lebih jauh menjadi pemicu semakin timpangnya jarak kesenjangan antar subregional, yakni: perbedaan keanggotaan dan minimnya manfaat hubungan pembangunan antar subregional, sinergi pemerintah pusat dan daerah, dan perbedaan orientasi kerjasama (ADB: 2010). Pertama, perbedaan tingkatan keanggotaan dan keterbatasan manfaat dari hubungan pembangunan antar subregional. Keanggotaan di GMS seluruhnya adalah negara kecuali dua provinsi Cina. Meskipun pada tahap tertentu, seperti pembangunan koridor-koridor ekonomi di GMS, pelibatan otoritas daerah sangat diperlukan karena fokus pada wilayah yang terbatas. Sementara itu, BIMP-EAGA seluruh anggotanya melibatkan provinsi kecuali Brunei Darussalam, begitu juga dengan IMT-GT yang keanggotaanya hanya melibatkan sebagaian dari wilayah negara-negara yang terlibat. Perbedaan keanggtaan ini tentunya berdampak pada pola dan efektifitas kerjasama masingmasing subregional.

Pola pengorganisasian subregional juga berbeda satu sama lain dan cenderung tumpang tindih. KTT BIMP-EAGA dan IMT-GT dilaksanakan setiap tahun sebagai bagian yang tidak terpisah dari KTT ASEAN, sementara KTT GMS dilakukan setiap tiga tahun sekali. Masing-masing subregional memiliki agenda berupa pertemuan puncak, pertemuan tingkat menteri, pertemuan pejabat senior, kelompok kerja (cluster dalam BIMP-EAGA), sekretariat subregional, dan sekretariat nasional di setiap negara. Meski begitu, tidak seperti kerjasama ASEAN yang dipimpin oleh kementerian luar negeri dan ekonomi, ketiga program subregional berada di bawah yurisdiksi kementerian dan pemerintah daerah yang berbeda-beda. Hal ini telah menciptakan inefisiensi dalam proses dan pengaturan kelembagaan. Ada kebutuhan untuk merampingkan dan memperkuat mekanisme kelembagaan antara instansi pemerintah nasional untuk memungkinkan koordinasi yang efektif antara tiga program dan ASEAN.

Kedua, sinergi kebijakan antara pemerintah pusat dan pemerintah daerah. Kendala-kendala BIMP-EAGA dan IMT-GT 
dalam menjalankan inisiatifnya sering terkendala karena tanpa didukung peran pemerintah pusat. Sistem politik di negaranegara GMS khususnya CLMV dan Cina yang cenderung sentralistis membuat kebijakan ditingkat subregional lebih mudah diimplementasikan secara sinergis hingga ke tingkat daerah. Sementara di negara-negara yang lebih demokratis seperti Indonesia, memiliki kesulitan dalam mengambil manfaat dari kerjasama subregional karena adanya otonomi daerah. Kepentingan daerah sering kali berbeda dan tidak mendapat dukungan secara solid dari di tingkat nasional. Pemerintah pusat cenderung melihat kepentingan daerah sebagai sesuatu yang sekunder dalam negosiasi internasional.

Ketiga, perbedaan orientasi kerjasama. GMS misalnya telah lama melibatakan proyekproyek pembangunan dan strategi pembangunan sektoral, sementara BIMPEAGA dan IMT-GT baru memulai orientasi semacam itu. Terkait dengan konektivitas misalnya, GMS cukup berhasil membangun infrastruktur yang terintegrasi dengan koridorkoridor ekonomi dalam program terukur di bawah GMS Strategic Framework. Sementara itu, BIMP-EAGA dan IMT-GT masih memiliki kendala dalam membangun konektivitas infrastruktur dan mendorong pembentukan jaringan produksi dan rantai suplai. Kendala membangun konektivitas infrastruktur jelas mengurangi efektivitas peran subregional sebagai building block bagi
MEA. Karenanya persoalan ini tidak hanya menjadi kendala dalam dalam koordinasi ditingkat ASEAN tetapi juga lebih jauh memicu kesenjangan pembangunan antar subregional dan menghambat manfaat maksimal dari integrasi ekonomi regional. 


\section{Daftar Pustaka}

Buku

ADB (2010), Bridges across Oceans: Initial Impact Assessment of the Philippines Nautical Highway System and Lessons for Southeast Asia, Philippines: Asian Development Bank.

ADB (2011), The Greater Mekong Subregion Economic Cooperation Program Strategic Framework 2012-2022, Philippines: Asian Development Bank.

ASEAN Secretariat (2011), ASEAN Community in Figure (ACIF) 2010. Jakarta: Public Outhreach and Civil Society Division of the ASEAN Secretariat.

ASEAN Secretariat (2012), ASEAN Community in Figure (ACIF) 2014. Jakarta: Public Outhreach and Civil Society Division of the ASEAN Secretariat.

Farrell, Mary (2005), "The Global Politics of Regionalism: An Introduction", in Mary Farrell, Bjorn Hettne and Luk Van Langenhove (eds), Global Politics of Regionalism: Theory and Practice, London: Pluto Press, pp. 1-20.

Glosny, Michael A. (2007), Stabilizing the Backyard: Recent Developments in China's Policy Toward Southeast Asia, dalam Joshua Eisenman, Einsenman, Eric Heginbotham, dan Derek Mitchell (eds), China and The Developing World: Beijing Strategy for the TwentyFirs Century, New York, East Gate Book, pp 150-186.

Li, Mingjiang and Chong Guan KWA, eds., (2011), China-ASEAN Sub-Regional Cooperation: Progress, Problems, and Prospect, Singapura: World Scientific Publishing Co. Pte. Ltd.

Lim, Chong-Yah (2004), Southeast Asia: The Long Road Ahead, Singapura: World Scientific Publishing Co. Pte. Ltd.

Lloyd, Peter J. (2007), What is Single Market: An Application to the Case of ASEAN, dalam Denis Hew (ed), Brick by Brick: The Building of an ASEAN Economic Community, Singapura: ISEAS Publishing, pp.13-35.

Marks, Gary (1993), "Structural Policy and Multilevel Governance in the EC", in A. Cafruny and G. Rosenthal (eds), The State of the European Community Vol. 2: The Maastricht Debates and Beyond, Lynne Rienner: Boulder, pp. 391-410.

McGregor, Andrew (2008), Southeast Asian Development, London \& New York: Routledge.

Narjoko, Dionisius, Pratiwi Kartika dan Teguh Wicaksono (2009), "Narrowing the Development Gap in ASEAN", dalam Michael G. Plummer dan Chia Siow Yue, eds, Realizing the ASEAN Economic Community: A Comprehensie Assessment, Singapura: ISEAS Publishing, pp. 116-141.

Pettman, R. (2009), "China's Region-building Strategy in Southeast Asia”, in E. Kavalski (ed.), China and the Global Politics of Regionalization, Surrey: Ashgate, pp. 139-152.

Pramono, Siswo (ed) (2011), ASEAN Connectivity in Indonesian Context: A Preliminary Study on Geopolitics of Hydro Power and Maritim Transport, Jakarta: Pusat Pengkajian dan Pengembangan Kebijakan Kawasan Asia-Pasifik dan Afrika (P3K2 Aspasaf), BPPKKementerian Luar Negeri Republik Indonesia.

Severino, Rodolfo C. (2006), Southeast Asia in Search of an ASEAN Community: Insights from the former ASEAN Secretary-General, Singapura: Institute of Southeast Asian Studies.

Severino, Rodolfo C. (2008), ASEAN, Singapore: Institute of Southeast Asian Studies. 
Söderbaum, Fredrik (2005), "Exploring the Links between Micro-Regionalism and MacroRegionalism", in Mary Farrell, Bjorn Hettne and Luk Van Langenhove (eds), Global Politics of Regionalism: Theory and Practice, London: Pluto Press, pp. 87-101.

uteethorn, Chularat (2009), "Economic Cooperation between Thailand and India and its Implications for the Asian Community," in Masahisa Fujita (ed.), Economic Integration in Asia and India, New York: Palgrave Macmillan, 89-115.

Sutter, R.G. (2010), "China's 'Backyard' Relations With the Korean Peninsula and Southeast Asia", in S. Breslin (ed.), Handbook of China's International Relations, London: Routledge, pp. 147-155.

Tong, Sarah Y. and Catherine Chong Siew Keng (2011), "ASEAN Economic Growth Triangles and Implications for China", in Mingjiang Li and Chong Guan KWA (eds), China-ASEAN Sub-Regional Cooperation: Progress, Problems, and Prospect, Singapore: World Scientific Publishing pp. 77-93.

Tongzon, Jose L. (2002), The Economies of Southeast Asia: Before and After the Crisis, $2^{\text {nd }}$ edition, Cheltenham: Edward Elgar.

Yue, Chia Siow (1997), "Regionalism and Subregionalism in ASEAN: The Free Trade Area and Growth Triangle Model", in Takatoshi Ito and Anne O. Krueger (eds), Regionalism versus Multilateral Trade Arrangements, Chicago: The University of Chicago Press, pp. 275302.

\section{Jurnal}

Alavi, Dr Rokiah and Aisha Al-Alim Ramadan (2008), "Narrowing Development Gaps in ASEAN", Journal of Economic Cooperation, 29 (1), pp. 29-60.

Hettne, Bjorn and Fredrik Söderbaum (1999), "Towards Global Social Theory", Journal of Internationa Relations and Development, Vol. 2 (4), pp. 358-368.

Landingin, Nathaniel and David Wadley (2005), "Export Processing Zones and Growth Triangle Development: The Case of the BIMP-EAGA, Southeast Asia," Journal of International Development, Vol. 17, pp. 67-96.

Leong, Ho Khai (2001), "Rituals, Risks, and Rivalries: China and ASEAN in the Coming Decades", Journal of Contemporary China, Vol. 10 (29), pp. 683-694.

Marks, Gary, Liesbet Hooghe and Kermit Blank (1996), "European Integration from the 1980s: State-Centric v. Multi-level Governance", Journal of Common Market Studies, Vol. 34 (3), pp. 350-356.

Narjoko, Dionisius dan Puspa Delima Amri (2007), "The Delopmental Gap Between the ASEAN Member Countries: The Perspective of Indonesia", ASEAN Ecnonomic Bulletin, Vol. 24 (1), pp.15-34.

Salazar, Lorraine Carlos dan Sanchita Basu Das (2007), "Bridging the ASEAN Developmental Divide: Challenges and Prospects", ASEAN Economic Bulletin, 24 (1), pp. 1-14.

Severino, Rodolfo C. (2007), "The ASEAN Developmental Divide and the Initiative for ASEAN Integration", ASEAN Economic Bulletin, Vol. 24 (1), pp. 35-44.

Stubbs, Paul (2005), "Stretching Concepts Too Far? Multi-Level Governance, Policy Transfer and the Politics of Scale in South East Europe," Southeast European Politics, Vol. 4 (2), November 2005, pp. 66 - 87.

Tongzon, Jose L. and Habibullah Khan (2005), "The Challenges of Economic Integration for Transitional Economies of Southeast Asia: Coping with Revenue Losses", ASEAN Economic Bulletin, Vol. 22, No. 3, December 2005, pp. 226-283. 


\section{Dokumen}

ADB (2004), "Prioritizing Strategic Directions for BIMP-EAGA: Final Report", ADB TA No. 6059 -REG, http://www.adb.org/BIMP/default.asp (diakses pada 13 February 2012).

ADB (2010), "Promoting Links and Improving Coordination Among the Greater Mekong Subregion (GMS), the Brunei Darussalam-Indonesia-Malaysia-Philippines East ASEAN Growth Area (BIMP-EAGA), the Indonesia-Malaysia-Thailand Growth Triangle (IMTGT), and the Association of Southeast Asian Nations (ASEAN)", Technical Assistance Report, Project Number: 44175-01, December 2010.

ASEAN Secretariat (1997), “ASEAN Vision 2020”. http://www.aseansec.org/1814.htm (diakses pada 26 Mei 2011).

ASEAN Secretariat (2000), "Initiative for ASEAN Integration and Narrowing the Development Gap". http://www.asean.org/23090.htm (diakses pada 26 Mei 2011).

ASEAN Secretariat (2001), "Ha Noi Declaration On Narrowing Development Gap For Closer ASEAN Integration". http://www.asean.org/3717.htm (diakses pada 26 Mei 2011).

ASEAN Secretariat (2002), "IAI Work Plan. Narrowing the Development Gap within ASEAN: $\square$ Assisting New Member Countries $\square$ (Cambodia, Laos, Myanmar and Viet Nam) July 2002 - June 2008". http://www.asean.org/14237.htm (diakses pada 26 Mei 2011).

ASEAN Secretariat (2003), "Declaration of ASEAN Concord II (Bali Concord II)". http:// www.asean.org/15159.htm (diakses pada 26 Mei 2011).

ASEAN Secretariat (2008), "Status Update of The IAI Work Plan I (2008-2008)".

ASEAN Secretariat (2009), "Initiative for ASEAN Integration (IAI) Strategic Framework and IAI Work Plan 2 (2009-2015)".

ASEAN Secretariat (2009), "Status Update of IAI Work Plan I (2002-2008)."

ASEAN Secretariat, "Narrowing the Development Gap within ASEAN: Assisting the New Member Countries (Cambodia, Laos, Myanmar and Viet Nam) Juny 2002-July 2008”. Lihat di http://www.asean.org/14237.htm (diakses pada 26 Mei 2011).

Bhattacharyay, Biswa Nath (2009), "Infrastructure Development for ASEAN Economic Integration", ADB Working Paper Series, No. 138, May 2009.

BIMP-EAGA (2006), "BIMP-EAGA Roadmap to Development 2006-2010", dapat di-download di http://www.aseansec.org/18500.htm (diakses pada 12 Februari 2012).

BIMP-EAGA (2008), "Midterm Review of the BIMP-EAGA Roadmap to Development (20062010)", Manila. (Consultant's report).

IMT-GT (2010), "Mid-term Review of the IMT-GT Roadmap for Development: 2007-2011, Midterm ADB (2011), Review of the Indonesia-Malaysia-Thailand Growth Triangle (IMTGT) Roadmap for Development: 2007-2011”, http://www.adb.org/publications/mid-termreview-imt-gt-roadmap-development-2007-2011 (diakses pada12 Februari 2011).

IMT-GT (2010), "Mid-term Review of the Indonesia-Malaysia-Thailand Growth Triangle (IMTGT) Roadmap for Development 2007-2011”, http://www.adb.org/publications/mid-termreview-imt-gt-roadmap-development-2007-2011 (diakses pada12 Februari 2011).

IMT-GT Secretariat and ADB (2008), "Building A Dynamic Future: Roadmap for Development 2007-2011". 
Menon, Jayant and Anna Cassandra Melendez (2011), "Trade and Investment in the Greater Mekong Subregion: Remaining Challenges and the Unfinished Policy Agenda", $A D B$ Working Paper Series on Regional Economic Integration, No. 78, May 2011.

Min Tang and Myo Thant (1993), "Growth Triangles: Conceptual Issues and Operational Problems", Makalah dipresentasikan dalam Workshop on "Growth Triangles in Asia", ADB, Manila, February 1993.

Petri, Peter A. (2008), "Competitiveness and Leverage: Benefits from an ASEAN Economic Community", makalah disampaikan pada "Conference on Realizing the AEC: A Comprehensive Assessment", Bangkok, 26-27 July, 2008.

Söderbaum, Fredrik (2008), "Consolidating Comparative Regionalism: From Euro-centrism to Global Comparison", Makalah untuk Konferensi Tahunan the GARNET 2008, Sciences Po Bordeaux, University of Bordeaux, Panel: "New Approaches in the Study of Regional Integration: Comparing the EU with Other Regional Integration Mechanisms", 17-19 September 2008.

Stone, Susan and Anna Strutt (2009), "Transport Infrastructure and Trade Facilitation in the Greater Mekong Subregion", ADB Institute Working Paper Series, No, 130, Januari 2009.

Trace, Keith, Barend Frielink, and Denis Hew (2009), "Maritime Connectivity in Archipelagic Southeast Asia: An Overview," ADB Southeast Asia Working Paper Series, No. 1, Agustus 2009.

Wade, Geoff (2010), “ASEAN Divides”, Australia: New Mandala.

Yue, Chia Siow (2006), "Integrating the Mekong Region into ASEAN", makalah presentasi disampaikan pada Seminar "Accelerating Development in the Mekong Region - The Role of Economic Integration”, pada 26-27 Juni 2006 di Siem Reap, Kamboja. 